\title{
Kinetics of Systemic Invasion and Latent and Incubation Periods of Tomato severe rugose virus and Tomato chlorosis virus in Single and Co-Infections in Tomato Plants
}

\author{
Gabriel Madoglio Favara, ${ }^{1}$ Daiana Bampi, ${ }^{1}$ Juan Pablo Edwards Molina, ${ }^{2}$ and Jorge Alberto Marques Rezende $1, \dagger$
}

'Department of Plant Pathology and Nematology, University of São Paulo, Piracicaba, São Paulo 13418-900, Brazil; and ²Instituto Nacional de Tecnología Agropecuaria, Instituto de Patología Vegetal-CIAP, 5020 Córdoba, Argentina. Accepted for publication 5 September 2018.

\begin{abstract}
Tomato severe rugose virus (ToSRV) and Tomato chlorosis virus (ToCV) are among the major viruses that affect tomato (Solanum lycopersicum) development and yield in Brazil. ToSRV and ToCV are transmitted in a persistent circulative and semipersistent manner, respectively, by the whitefly Bemisia tabaci Middle East-Asia Minor 1, considered the main vector of these viruses. In this study, the kinetics of systemic invasion and the latent and incubation periods of ToSRV and ToCV were evaluated in singly and doubly infected tomato plants. Both viruses moved systemically into tomato plants as early as 1 day after inoculation. The mean ToCV

latent periods in single infections and co-infections with ToSRV were 13 and 11 days, respectively, while incubation periods in single and coinfections were, on average, 30 and 31 days, respectively. For ToSRV, the mean latent period was 7 days in single infections and 6 days in coinfections with ToCV. Incubation periods were, on average, 18 and 17 days in single and co-infections, respectively. Because latent periods for both viruses were shorter than their respective incubation periods, field-infected tomato plants may act as sources of inocula soon after infection and before onset of symptoms.
\end{abstract}

Tomato (Solanum lycopersicum, family Solanaceae) is one of the most important vegetables in the world, generating a large number of jobs in both agriculture and industry, and is a source of high-value nutrients and minerals for human consumption (Bergougnoux 2014). Among factors that may compromise the development and production of tomato, the diseases caused by Tomato severe rugose virus (ToSRV; genus Begomovirus) and Tomato chlorosis virus (ToCV; genus Crinivirus) are particularly noteworthy (Inoue-Nagata et al. 2016a,b).

In Brazil, 17 species of the genus Begomovirus that naturally infect tomato plants in the field have been described (Fernandes et al. 2008; Inoue-Nagata et al. 2016a,b; Rocha et al. 2013). ToSRV is the predominant begomovirus in the main tomato-producing regions in Brazil: the states of Minas Gerais, São Paulo, and Goiás and the Federal District (Inoue-Nagata et al. 2016a,b). To date, ToCV is the only crinivirus reported as infecting tomato plants in Brazil (Barbosa et al. 2011; Inoue-Nagata et al. 2016a). ToSRV and ToCV are transmitted in a persistent circulative and semipersistent manner, respectively, by different species of whiteflies. The cryptic species Bemisia tabaci Middle East-Asia Minor 1 (MEAM1, formerly biotype B), because it predominates in different regions and shows high efficiency in transmitting ToSRV and ToCV, is considered the principal vector of these viruses in Brazil (Barbosa et al. 2014; De Marchi et al. 2017; Marubayashi et al. 2013; Rocha et al. 2011). Both viruses can also be transmitted by B. tabaci New World 2 (NW2, formerly biotype A) (De Marchi et al. 2017). B. tabaci New World 1 (NW1, formerly biotype A), B. tabaci Mediterranean (MED, formerly biotype Q), Trialeurodes abutiloneus, and T. vaporariorum are also vectors of ToCV (Lourenção et al. 2008; Orfanidou et al. 2016; Wintermantel and Wisler 2006). Of these, only T. abutiloneus has not

${ }^{\dagger}$ Corresponding author: Jorge Alberto Marques Rezende; E-mail: jrezende@usp.br

Funding: This study was supported by the Fundação de Amparo à Pesquisa do Estado de São Paulo (FAPESP), project numbers 2012/51771-4, 2015/14876-0, and 2016/01628-1.

(c) 2019 The American Phytopathological Society yet been reported in Brazil. There is no apparent interaction between ToSRV and ToCV in the processes of acquisition and transmission by B. tabaci MEAM1, because transmission rates when these viruses were acquired simultaneously or individually are similar (Macedo et al. 2019).

ToSRV-induced symptoms in tomato plants include vein clearing, chlorosis, mosaic, and foliar wrinkling that affect plant development (Inoue-Nagata et al. 2016a,b; Macedo et al. 2015). Tomato plants infected with ToCV exhibit mostly interveinal chlorosis on older leaves, which may also show bronzing or reddish spots and upward-curved edges, eventually becoming thick and brittle. Symptoms begin at the base and progress toward the plant apex but rarely appear on younger leaves (Wintermantel and Wisler 2006; Wintermantel et al. 2008).

Due to the presence of common hosts of these viruses in the field, including cultivated plants and weeds, and because both are transmitted by $B$. tabaci MEAM1, co-infections in tomato crops frequently occur in Brazil (Inoue-Nagata et al. 2016a; Macedo et al. 2014). A study of tomato plants in Goiás and the Federal District found that, of 150 samples analyzed, $40 \%$ were infected with both viruses, while 32 and $20 \%$ contained only ToCV or ToSRV, respectively (Macedo et al. 2014). Greenhouse experiments showed that tomato plants co-infected early with ToSRV and ToCV may have drastically reduced yield (Guimarães et al. 2017).

Epidemiological studies have shown that the spatial and temporal dynamics of ToSRV and ToCV in tomato crops are very similar and that, for both viruses, primary infections through the continuous influxes of viruliferous whiteflies are the main factor responsible for epidemics (Macedo et al. 2019). However, important epidemiological parameters such as latent and incubation periods are still unknown for ToSRV and ToCV in tomato plants. Knowledge of latent and incubation periods of pathogens in their hosts is important to the development of strategies for managing plant diseases (Rimbaud et al. 2015). Latent period can be defined as the time between inoculation and host infectivity (i.e., the time when the infected plant becomes a source of inoculum) and incubation period as the time interval from inoculation of the pathogen into the host until symptoms appear (Bergamin Filho et al. 2018; Rimbaud et al. 2015; Van Der Plank 1963). 
Control of both diseases has been difficult and, in general, it is recommended that management measures for these viruses be carried out on a regional scale and involve integrated management with the use of various practices, including transplanting healthy seedlings; using resistant or tolerant cultivars, which are currently available only for begomoviruses; establishing a virus-free tomato crop period; avoiding scaling of plantations; eliminating external sources of inocula; and rational control of the insect vector by applying insecticides (Bergamin Filho et al. 2016; Gouvêa et al. 2017; Inoue-Nagata et al. 2016a,b).

To better understand the important epidemiological parameters for the development of diseases associated with ToSRV and ToCV and to assist in establishing more effective management measures, we evaluated the kinetics of systemic invasion and the latent and incubation periods of these viruses in single infections and coinfections in tomato plants.

\section{MATERIALS AND METHODS}

Plant material. Healthy tomato plants (type Santa Cruz, cultivar Kada) grown from seed sown in 1.5-liter pots containing commercial substrate (Tropstrato HT Hortaliças) were used. Approximately 20 seeds were sown per pot. After reaching the three- to four-true-leaf stage, plants were transplanted to new 1.5-liter pots containing the same substrate, with one plant per pot. Plants were irrigated daily and fertilized periodically with N-P-K (10-10-10).

Virus isolates. The ToCV isolate used in the experiments was collected from infected tomato plants in the municipality of Sumare, state of São Paulo, Brazil. The ToSRV isolate used in the first experimental replicate was kindly provided by Dr. Alice Kazuko Inoue-Nagata, Embrapa Hortaliças, Distrito Federal. In the other replicates, an isolate of ToSRV obtained from infected tomato plants in Sumaré was used. The identity of the virus isolates was confirmed through partial nucleotide sequencing of their genomes and comparison with other corresponding nucleotide sequences deposited in GenBank, using the program BLASTn, available at https://www.ncbi. nlm.nih.gov/blast. ToCV- or ToSRV-infected tomato plants were maintained separately in plant growth chambers (Conviron) at a temperature of $25^{\circ} \mathrm{C}$ with a photoperiod of $14 \mathrm{~h}$ of light and $10 \mathrm{~h}$ of darkness. Tomato plants co-infected with ToSRV and ToCV isolates were maintained in whitefly-proof cages in a greenhouse. Sources of inoculum were renewed periodically by transmitting the viruses to young tomato plants, using $B$. tabaci MEAM1.

Colony of B. tabaci MEAM1. A virus-free colony of B. tabaci MEAM1 was used for the transmission assays. The colony was established in collard plants (Brassica oleraceae) and kept in whitefly-proof cages. Periodically, the species identity and colony purity were molecularly verified. Total DNA of adult insects was extracted by using the Chelex 100 protocol (Walsh et al. 1991) and amplified by polymerase chain reaction (PCR) using the primer pair Bem23F and Bem23R, which differentiate the cryptic species Bemisia tabaci MEAM1 and MED (De Barro et al. 2003).

Transmission of viruses by $B$. tabaci MEAM1. With a mouth aspirator, virus-free $B$. tabaci MEAM1 adults were collected from collard leaves and transferred to glass pots $(600 \mathrm{ml})$ containing tomato leaves infected with ToSRV and ToCV isolates, separately. The insects were provided an acquisition access period (AAP) of $24 \mathrm{~h}$. To transmit both viruses together, detached leaves of tomato plants coinfected with ToSRV and ToCV were used as an inoculum source, because simultaneous acquisition of these viruses does not affect the efficiency of vector transmission, as mentioned previously. After the AAP, the potentially viruliferous insects were transferred to clip cages and placed on leaflets of tomato plants to be inoculated. An inoculation access period (IAP) of $24 \mathrm{~h}$ was used for the assays of kinetics of systemic invasion, and an IAP of 5 days was used for the assays to determine the latent and incubation periods. To prevent possible crosscontamination between plants after IAP, inoculated leaves together with clip cages were detached from the plants, thus eliminating all adult insects and any deposited eggs and eventual nymphs. Then, plants were sprayed with the insecticides pyriproxyfen and cartap hydrochloride to prevent later colonization by the vector. Plants were kept in whitefly-proof cages in a greenhouse.

Nucleic acid extraction. Total DNA and RNA were extracted from leaf samples according to Dellaporta et al. (1983), with adaptation. In a microfuge tube, $0.1 \mathrm{~g}$ of leaf sample was macerated in liquid nitrogen. In total, $750 \mu \mathrm{l}$ of nucleic acid extraction buffer (100 mM Tris-Cl, $50 \mathrm{mM}$ EDTA, and $500 \mathrm{mM} \mathrm{NaCl}, \mathrm{pH} 8.0$ ) and $50 \mu \mathrm{l}$ of $20 \%$ sodium dodecyl sulfate was added to the ground tissue. The sample was then incubated at $65^{\circ} \mathrm{C}$ for $10 \mathrm{~min}$. Then, $250 \mu \mathrm{l}$ of $3 \mathrm{M}$ potassium acetate was added, and the sample was kept on ice for $20 \mathrm{~min}$ and centrifuged at $12,000 \times g$ at $4^{\circ} \mathrm{C}$ for $20 \mathrm{~min}$. The supernatant was transferred to a new tube and $680 \mu \mathrm{l}$ of isopropanol was added. The sample was incubated at $20^{\circ} \mathrm{C}$ for $30 \mathrm{~min}$ and then centrifuged at $12,000 \times g$ at $4^{\circ} \mathrm{C}$ for $20 \mathrm{~min}$. Subsequently, the supernatant was discarded and the pellet was vacuum dried for $5 \mathrm{~min}$. The pellet was then resuspended in $100 \mu \mathrm{l}$ of $1 \times$ Tris-EDTA (TE) buffer (10 mM Tris-Cl and $1 \mathrm{mM}$ EDTA, $\mathrm{pH}$ 8.0), and the suspension was kept on ice for $15 \mathrm{~min}$. Then, $10 \mu \mathrm{l}$ of $3 \mathrm{M}$ sodium acetate, $\mathrm{pH}$ 5.2, and $250 \mu \mathrm{l}$ of $95 \%$ ethanol were added. The suspension was kept at $-20^{\circ} \mathrm{C}$ for $30 \mathrm{~min}$, then centrifuged at $12,000 \times g$ for $20 \mathrm{~min}$ at $4^{\circ} \mathrm{C}$. The pellet was washed with $150 \mu \mathrm{l}$ of $70 \%$ ethanol and centrifuged at $12,000 \times g$ for $10 \mathrm{~min}$ at $4^{\circ} \mathrm{C}$, and the supernatant was discarded. The pellet was vacuum dried for $5 \mathrm{~min}$ and resuspended in $50 \mu \mathrm{l}$ of $0.1 \times \mathrm{TE}$ buffer and stored at $-20^{\circ} \mathrm{C}$ for later use in rolling-circle amplification (RCA)-PCR and reverse-transcription (RT)-PCR.

Detection of ToSRV by RCA-PCR and of ToCV by RTPCR. The presence of ToSRV and ToCV was analyzed from the total DNA and RNA extracted from leaf samples, respectively. Total DNA and RNA extracted from tomato plants with confirmed infection with ToSRV or ToCV and from healthy plants were used in RCA-PCR and RT-PCR as positive and negative controls, respectively. To check for possible cross-contamination between plants, leaf samples from some tomato plants inoculated with ToSRV alone were randomly selected and analyzed molecularly to detect ToCV, while other plants inoculated with ToCV alone were selected and analyzed to detect ToSRV.

After extraction of total DNA, an initial amplification was performed by the RCA technique with the enzyme phi29 DNA polymerase, using the Illustra TempliPhi kit (GE Healthcare) according to the manufacturer's recommendations. The RCA product was stored at $-20^{\circ} \mathrm{C}$ for later use in PCR. The PCR was performed using the universal oligonucleotide primers for begomoviruses, PAR1c496 and PAL1v1978, which amplify a fragment of approximately $1.1 \mathrm{kbp}$ comprising the $5^{\prime}$ region of the replicase gene, the entire intergenic region, and the $5^{\prime}$ region of the coat protein gene (Rojas et al. 1993). For detection of ToCV, the oligonucleotide primers ToC-5 and ToC-6, which amplify a fragment of approximately $463 \mathrm{bp}$ comprising the heat shock protein 70 homolog gene, were used (Dovas et al. 2002). Amplicons obtained were analyzed by electrophoresis in $1 \%$ agarose gels, stained with SYBR Safe DNA Gel Stain (Invitrogen), and visualized in a UV-transilluminator.

Nucleotide sequencing. To confirm the identity of the virus species that were detected by RCA-PCR and RT-PCR, some amplicons were randomly selected and sent for nucleotide sequencing. RCA-PCR and RT-PCR products were purified using the Wizard SV Gel purification kit and PCR Clean-up System (Promega Corp.), according to the manufacturer's recommendations. Purified amplicons were sent to Macrogen for sequencing. Nucleotide sequences obtained were compared with other corresponding nucleotide sequences available in GenBank, using the program BLASTn, available at https://www.ncbi.nlm.nih.gov/blast.

Kinetics of systemic invasion of ToSRV and ToCV in single and co-infection in tomato plants. Two independent experiments were conducted in a greenhouse in ambient temperature and photoperiod from January to March 2017 and July to September 2017. Tomato plants (cultivar Kada) were inoculated with ToSRV and 
ToCV, separately and together, 30 days after emergence. After a 24-h AAP of the viruses, 20 viruliferous adults of $B$. tabaci MEAM1 were confined in clip cages placed on the terminal leaflet of the third leaf of test tomato plants for a 24-h IAP. Then, the insects were killed inside the clip cages by applying carbon dioxide gas for $30 \mathrm{~s}$. Leaves inoculated with the virus by the vector were detached from the plants together with clip cages at the following time intervals: 1 , 2,3 , and 4 days after the viruliferous insects were confined on the plants. In 15 tomato plants, the inoculated leaf was not detached from the plant after the insects were killed, as a positive control for systemic invasion. After the inoculated leaves were removed, pyriproxyfen and cartap hydrochloride were applied to prevent subsequent colonization by the vector. Plants were kept in individual whitefly-proof cages to prevent cross-contamination between the experimental plants. Infection and systemic invasion of the virus or viruses in all tomato plants were confirmed 30 days after inoculation (DAI), using RCA-PCR for ToSRV and RT-PCR for ToCV.

Identification of latent and incubation periods of ToSRV and $\mathrm{ToCV}$ in single and co-infections in tomato plants. Three independent experiments were conducted in a greenhouse, with ambient temperature and photoperiod during November 2016 to February 2017, February to May 2017, and July to October 2017. Tomato plants were inoculated with the viruses, separately and mixed, 30 days after emergence. Procedures for virus acquisition and inoculation were performed as described previously. For inoculation, 30 viruliferous insects per plant and a 5-day IAP were used. Inoculated tomato plants were subsequently used as inoculum sources for acquisition of the viruses by B. tabaci MEAM1 in transmission assays conducted at different time intervals. Tomato plant sources of inocula were used for virus acquisition by the vector at $4,8,12$, and 16 DAI.

For virus acquisition, 50 virus-free adult whiteflies were confined in clip cages and were always placed on the newest fully developed leaf of the inoculum source plants at each acquisition time interval assessed. For each preestablished acquisition time, the AAP for the vector was $24 \mathrm{~h}$. Subsequently, the insects were transferred to other clip cages and placed on the terminal leaflet of the third leaf of healthy tomato plants. Tomato test plants were inoculated 25 to 30 days after emergence. For inoculation, approximately 30 viruliferous insects per plant were confined for a 5-day IAP. In all acquisition intervals, the same plants were used as sources of inocula. For each virus-acquisition interval, insects that acquired the viruses on a tomato inoculum source were used to inoculate a tomato test plant. After inoculation, test plants were kept in individual cages in the greenhouse and sprayed with pyriproxyfen and cartap hydrochloride to kill whiteflies and avoid possible cross-contamination between experimental plants.

Latent periods were evaluated based on transmission of ToSRV and ToCV by B. tabaci MEAM1 to tomato test plants after the whiteflies acquired the viruses from the tomato sources of inoculum at each different time interval after inoculation. Transmission of viruses was determined for all plants 30 DAI by RCA-PCR for ToSRV and by RTPCR for ToCV. Incubation periods of ToSRV and ToCV in tomato plants were evaluated daily based on the appearance of symptoms in the plants used as sources of inocula.

Two experiments were conducted according to the procedures described above. A third experiment was carried out, differing from the previous experiments only in the time intervals for acquisition of the viruses from the plant sources of inoculum. In the third experiment, acquisitions of the viruses by the vector were conducted daily, from days 1 to 8 after inoculation for tomato plants inoculated with ToSRV; from days 4 to 12 after inoculation for plants inoculated with ToCV; and from days 1 to 12 after inoculation for plants doubly inoculated with ToSRV and ToCV. Evaluations followed the same criteria described above.

Statistical analysis. Binary logistic regression analysis was used to assess the kinetics of systemic invasion of ToSRV and ToCV in single and co-infections in tomato plants (Madden et al. 2002;
Mituti et al. 2018). Logistic function was fitted to model the relationship between plant infection status $(0=$ noninfected and $1=$ infected) and removal time of inoculated leaves (1, 2, 3, or 4 DAI). This relationship was tested to determine whether it was affected by the virus and the type of infection (single versus co-infection).

The generalized linear model with binomial error structure and logit link function for each individual experiment can be written as logit $\left(p_{i j k}\right)=\ln [p /(1-p)]=\mu+\alpha_{i}+\beta_{i}+\delta_{k}+(\alpha \beta \gamma)_{i j k}+(\alpha \beta)_{i j}+(\alpha \gamma)_{i k}+(\beta \gamma)_{j k}$, where $p_{i j k}$ is the probability of a tomato plant being infected on day $i$ after inoculated leaf removal for virus $j$ and type of inoculation $k$ (single or in co-inoculation); $\mu$ is a constant.

The significance of the predictor variables $(\alpha, \beta, \delta$, and their double and triple interactions) were tested in the deviance analysis by the Wald statistic z-value. Plots of $p$ [obtained by back-transformation of the logit $(p)$ ] as a function of removal time of inoculated leaves for both viruses in single or co-infection were done for better understanding of the results.

Survival analysis technique was used to estimate both latent and incubation periods because it is a suitable tool to deal with time-toevent variables. The advantage of this analysis technique is that it can accommodate censored observations (i.e., cases in which the event has not occurred by the end of the study) (Hosmer and Lemeshow 1999; Scherm and Ojiambo 2004). Cox proportional hazards regression models were fitted to (i) time (days) when the infected plant becomes a source of inoculum (latent period) and (ii) time (days) from the inoculation until the appearance of the typical symptoms of each virus (incubation period) (Copes and Thomson 2008; Lanza et al. in press). The Kaplan-Meier method was used to produce estimates of the latent and incubation curves and median period lengths. The median period lengths of both variables were compared using a $\log$-rank test (at $P=0.05$ ), which tested whether they were affected by the type of virus (ToCV or ToSRV) or when they were inoculated in single or co-infections.

All statistical analyses were performed using R (R Team 2018). The "glm" function from the stats package was used to fit the binary data and "predict" function for back-transforming the estimated $\operatorname{logit}(p)$ to probability scale. The "coxph" and "survfit" functions from the survival package were used to fit the survival curves and Cox proportional hazards regression models, respectively. For a better comprehension of results, the survival curves were transformed to their cumulative event plots by $f(y)=1-y$. The "ggsurvplot" function from the survminer package was used to plot the survival curves (Kassambara and Kosinski 2018).

\section{RESULTS}

Identity of virus isolates and molecular analyses. Partial nucleotide sequences obtained from total DNA and RNA extracted from tomato plants used as sources of inoculum of ToSRV and ToCV showed 95 to $98 \%$ and 98 to $99 \%$ identity, respectively, with other corresponding sequences of ToSRV (accession numbers AYO29750 and JX415196) and ToCV (accession numbers JQ952601 and KY419528) deposited in GenBank. The nucleotide sequences of five amplicons obtained from the total DNA and RNA extracted from tomato plants infected with ToSRV and ToCV, respectively, and which were randomly selected in each experiment, confirmed the identity of the viral isolates. Tomato plants used as sources of inoculum were also tested by RT-PCR for the presence of other tomato-infecting viruses of the genera Potyvirus (Potato virus Y), Tobamovirus (Tomato mosaic virus), Orthotospovirus (Tomato spotted wilt virus and Tomato chlorotic spot virus), and Crinivirus (Tomato infectious chlorosis virus). The results were negative (data not shown).

Samples of tomato plants used to check cross-contamination showed that those inoculated with ToSRV alone tested negative by RT-PCR for the presence of ToCV, whereas those inoculated with ToCV alone tested negative by RCA-PCR for the presence of ToSRV. Neither of the viruses was detected in healthy tomato plants used as controls (data not shown). 
Kinetics of systemic invasion of ToSRV and ToCV in single and co-infections in tomato plants. The results for the kinetics of the systemic invasion of ToSRV and ToCV in tomato plants demonstrated that both viruses, in single and co-infections, moved systemically from the inoculated leaf within 1 DAI (Table 1).

The percentage of plants infected with ToSRV remained high with the different removal times of the inoculated leaves. For inoculated leaves removed at 1 DAI, the proportion of ToSRVinfected plants was higher than $50 \%$. This proportion did not increase when the inoculated leaves were removed at 2, 3, or 4 DAI (Fig. 1A and B). Statistical analysis indicated that co-infection with ToCV did not significantly influence the time required for ToSRV to move systemically from the inoculated leaf (Fig. 1A and B). The percentage of plants infected with ToCV increased as the inoculated leaf remained longer on the tomato plants (Fig. 1C and D). This percentage ranged from 8 to $19 \%$ when the inoculated leaf was removed from the plant at 1 DAI and increased up to 80 to $90 \%$ when the inoculated leaf was removed from the plant at 4 DAI (Table 1). In the first experiment, the co-infection with ToSRV affected the systemic invasion of ToCV, because the proportion of ToCV-infected plants reached $50 \%$ when the inoculated leaf was removed at 2.7 DAI in a single infection and at $1.5 \mathrm{DAI}$ in a coinfection (Fig. 1C). However, in the second experiment, coinfection with ToSRV did not significantly affect the systemic invasion of ToCV (Fig. 1D).

Latent and incubation periods of ToSRV and ToCV in single and co-infections in tomato plants. The minimum and mean latent periods of ToSRV in single infection in tomato plants were 4 and 7 days, respectively (Table 2; Fig. 2). The incubation period of ToSRV in tomato plants analyzed in experiments 1 and 2 could not be determined because the infected plants, for unknown reasons, did not show symptoms typical of those induced by this virus such as mosaic and foliar wrinkling. ToSRV infection was confirmed in all asymptomatic tomato plants by RCA-PCR. In the third experiment, tomato plants infected with ToSRV showed symptoms of vein clearing and foliar wrinkling, and some plants also showed mosaic on younger leaves. Symptoms were first expressed at 16 to 18 DAI. In tomato plants doubly inoculated with ToSRV and ToCV, the minimum and mean latent periods of ToSRV were 2 and 6 days, respectively. Doubly infected plants in experiments 1 and 2 also did not exhibit characteristic symptoms of begomovirus infection. The incubation period of ToSRV in co-infection with ToCV, evaluated only in experiment 3 , ranged from 16 to 18 days, similar to that of the single infection (Table 2; Fig. 2).

The minimum latent period of ToCV in a single infection was 7 days, with a mean of 13 days. The incubation period of this crinivirus in a single infection ranged from 21 to 41 days, with a mean of 30 days (Table 2; Fig. 2). The minimum latent period of ToCV in tomato plants co-infected with ToSRV was 6 days, with a mean of 11 days. Three tomato plants inoculated with both viruses and proven to be infected with ToCV did not serve as sources of inoculum of this crinivirus in the transmission intervals evaluated. The incubation period of ToCV co-infected with ToSRV ranged from 23 to 41 days, with a mean of 31 days (Table 2).

Latent and incubation periods of ToSRV and ToCV in tomato plants were significantly different $(P<0.0001)$ (Fig. 3A and D). Plants infected with ToSRV became sources of inoculum and symptomatic earlier than plants infected with ToCV. However, coinfection did not significantly alter the latent and incubation periods of either virus (Fig. 3B, C, E, and F).

\section{DISCUSSION}

Kinetics of systemic invasion of ToSRV and ToCV in single and co-infections in tomato plants. The results of the present study demonstrated that ToSRV and ToCV rapidly move systemically from the inoculated leaves of tomato plants (i.e., within a single day after inoculation of plants by viruliferous whiteflies). The

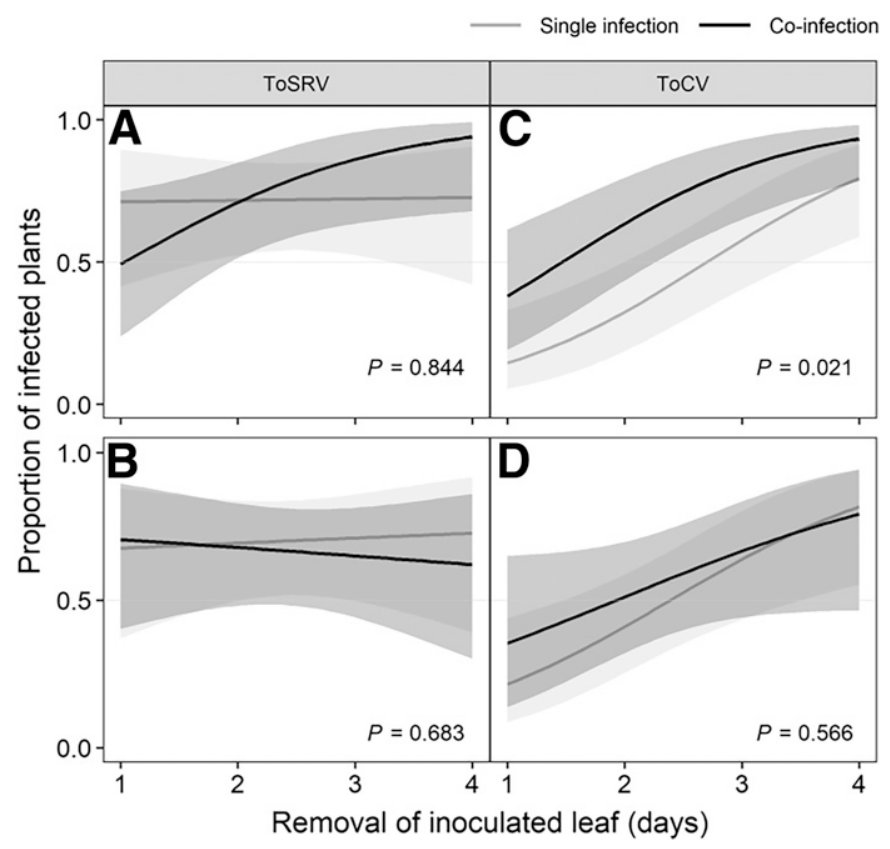

Fig. 1. Probability of tomato plants being infected as a function of the removal time of inoculated leaf. ToSRV $=$ Tomato severe rugose virus and $\mathrm{ToCV}=$ Tomato chlorosis virus. Gray shaded area represents the $95 \%$ confidence interval of the estimated proportions. Gray horizontal line indicates $50 \%$ infected plants. $P$ values represent the significance of the interaction term: time (in days) of inoculated leaf removal and type of infection (single or co-infection). $\mathbf{A}$ and $\mathbf{C}$, First experiment and $\mathbf{B}$ and $\mathbf{D}$, second experiment.

TABLE 1. Systemic invasion of Tomato severe rugose virus (ToSRV) and Tomato chlorosis virus (ToCV) in single and co-infection in tomato plants after removal of the inoculated leaf at different time intervals (days)

\begin{tabular}{|c|c|c|c|c|c|c|}
\hline & & \multicolumn{5}{|c|}{ Number of plants infected/number of plants inoculated (\% infection) } \\
\hline \multicolumn{2}{|c|}{ Experiment, virus } & \multicolumn{4}{|c|}{ Removal of inoculated leaf (days) } & \multirow[b]{2}{*}{ Undetached leaf $^{\mathrm{a}}$} \\
\hline Inoculated & Detected & 1 & 2 & 3 & 4 & \\
\hline \multicolumn{7}{|l|}{ First } \\
\hline ToSRV & ToSRV & $7 / 9(78)$ & $4 / 7(57)$ & $6 / 8(75)$ & $6 / 8(75)$ & $2 / 3(67)$ \\
\hline ToCV & ToCV & $1 / 12(8)$ & $3 / 10(30)$ & $8 / 14(57)$ & $9 / 10(90)$ & $2 / 2(100)$ \\
\hline Both & ToSRV & $5 / 10(50)$ & $6 / 8(75)$ & $6 / 8(75)$ & $8 / 8(100)$ & $2 / 2(100)$ \\
\hline Both & ToCV & $4 / 10(40)$ & $7 / 8(88)$ & $5 / 8(63)$ & $7 / 8(88)$ & $2 / 2(100)$ \\
\hline \multicolumn{7}{|l|}{ Second } \\
\hline ToSRV & ToSRV & $6 / 8(75)$ & $5 / 8(63)$ & $5 / 8(63)$ & $5 / 6(83)$ & $2 / 2(100)$ \\
\hline ToCV & ToCV & $3 / 16$ (19) & $4 / 8(50)$ & $5 / 8(63)$ & $8 / 10(80)$ & $2 / 3(67)$ \\
\hline Both & ToSRV & $8 / 8(100)$ & $2 / 8(25)$ & $5 / 8(63)$ & $5 / 6(83)$ & $3 / 3(100)$ \\
\hline Both & ToCV & $4 / 8(50)$ & $2 / 8(25)$ & $6 / 8(75)$ & $5 / 6(83)$ & $3 / 3(100)$ \\
\hline
\end{tabular}

a Control. 
infection rate of tomato plants with ToSRV was high, even with the removal of the inoculated leaf $1 \mathrm{DAI}$, whereas ToCV infection rate was increased when inoculated leaves remained longer on the plant (Table 1; Fig. 1). These results indicated a higher efficiency of the begomovirus at the beginning of the systemic invasion in tomato plants.

Several factors can influence the length of time viruses take to systemically invade the host: species, variety, and age of the host; species and strain of the virus; suppression of virus-induced host defenses such as RNA silencing; the environment; and the method and site of inoculation. It should also be considered that the rate of virus movement in mesophyll and epidermal cells is much lower than the rate of movement through the phloem vessels (Hull 2013).

Silva et al. (2002) evaluated the kinetics of the systemic invasion of the Cowpea mosaic virus (genus Comovirus) in cowpea (Vigna unguiculata) by removing mechanically inoculated primary leaves at

TABLE 2. Latent and incubation periods of Tomato severe rugose virus (ToSRV) and Tomato chlorosis virus (ToCV) in single and co-infection in tomato plants ${ }^{\mathrm{a}}$

\begin{tabular}{lcccc}
\hline Virus, & $\begin{array}{c}\text { Inoculum } \\
\text { source } \\
\text { experiment }\end{array}$ & $\begin{array}{c}\text { Latent } \\
\text { period } \\
\text { (days) }\end{array}$ & $\begin{array}{c}\text { Incubation } \\
\text { period } \\
\text { (days) }\end{array}$ & $\begin{array}{c}\text { Interval between } \\
\text { latent and } \\
\text { incubation (days) }\end{array}$ \\
\hline
\end{tabular}

\begin{tabular}{|c|c|c|c|c|}
\hline \multicolumn{5}{|l|}{ ToSRV } \\
\hline \multirow[t]{5}{*}{1} & 1 & 8 & as & - \\
\hline & 2 & 8 & as & - \\
\hline & 3 & 8 & as & - \\
\hline & 4 & 8 & as & - \\
\hline & 5 & 8 & as & - \\
\hline \multirow[t]{5}{*}{2} & 6 & 4 & as & - \\
\hline & 7 & 8 & as & - \\
\hline & 8 & 4 & as & - \\
\hline & 9 & 4 & as & - \\
\hline & 10 & 4 & as & - \\
\hline \multirow[t]{4}{*}{3} & 11 & 7 & 18 & 11 \\
\hline & 12 & 8 & 18 & 10 \\
\hline & 13 & 7 & 16 & 9 \\
\hline & 14 & 7 & 18 & 11 \\
\hline Mean & $\ldots$ & 7 & 18 & 11 \\
\hline \multicolumn{5}{|l|}{ ToCV } \\
\hline \multirow[t]{5}{*}{1} & 1 & 16 & 34 & 18 \\
\hline & 2 & 16 & 29 & 13 \\
\hline & 3 & 12 & 34 & 22 \\
\hline & 4 & 16 & 41 & 25 \\
\hline & 5 & 12 & 35 & 23 \\
\hline \multirow[t]{4}{*}{2} & 6 & 12 & 29 & 17 \\
\hline & 7 & 16 & 32 & 16 \\
\hline & 8 & 12 & 32 & 20 \\
\hline & 9 & 16 & 31 & 15 \\
\hline \multirow[t]{4}{*}{3} & 10 & 11 & 25 & 14 \\
\hline & 11 & 12 & 21 & 9 \\
\hline & 12 & 7 & 25 & 18 \\
\hline & 13 & 11 & 23 & 12 \\
\hline Mean & $\ldots$ & 13 & 30 & 17 \\
\hline \multicolumn{5}{|c|}{ ToSRV + ToCV } \\
\hline \multirow[t]{5}{*}{1} & 1 & $8 /-$ & as $/ 28$ & $-1-$ \\
\hline & 2 & $8 / 12$ & as/31 & $-/ 19$ \\
\hline & 3 & $8 / 16$ & as/27 & $-/ 11$ \\
\hline & 4 & $8 / 12$ & as $/ 26$ & $-/ 14$ \\
\hline & 5 & $8 / 16$ & as/34 & $-/ 18$ \\
\hline \multirow[t]{5}{*}{2} & 6 & $8 / 16$ & as $/ 37$ & $-/ 21$ \\
\hline & 7 & $4 /-$ & as/41 & $-1-$ \\
\hline & 8 & $4 /-$ & as/41 & $-1-$ \\
\hline & 9 & $4 / 12$ & as/39 & $-/ 27$ \\
\hline & 10 & $4 / 8$ & as $/ 37$ & $-/ 29$ \\
\hline \multirow[t]{4}{*}{3} & 11 & $5 / 6$ & $16 / 23$ & $11 / 17$ \\
\hline & 12 & $2 / 12$ & $16 / 25$ & $14 / 13$ \\
\hline & 13 & $2 / 8$ & $16 / 25$ & $14 / 17$ \\
\hline & 14 & $8 / 8$ & $18 / 25$ & $10 / 17$ \\
\hline Mean & $\ldots$ & $6 / 11$ & $17 / 31$ & $11 / 20$ \\
\hline
\end{tabular}

a Symbols: as = asymptomatic plants and - indicates parameter not determined. For combined viruses, the left side represents results for ToSRV and the right side represents results for ToCV. daily intervals. Systemic infection was established when the inoculated leaves were removed 2 DAI or later. A similar study with the begomoviruses Tomato rugose mosaic virus (ToRMV) and Tomato yellow spot virus (ToYSV), inoculated using bioballistics into Nicotiana benthamiana and tomato plants, revealed that both viruses were able to move systemically 2 and 4 DAI in N. benthamiana and tomato plants, respectively (Alves-Júnior et al. 2009). These results differ from those obtained for ToSRV in the present study because, here, the virus moved systemically only 1 DAI in tomato plants. Part of the divergence between the results obtained in the assays involving these begomoviruses may be related to the inoculation methods used. The inoculation method may influence the amount of time required for systemic invasion of the host plant because it influences the location where virus particles are deposited within host tissues. For phloem-limited viruses that are delivered by the insect vector directly into the vasculature, the initial cell-to-cell movement may not occur and the virus particles are transported long distances through the phloem almost immediately after inoculation (Hull 2013). This may explain the rapid onset of systemic movement of the begomovirus and crinivirus in the tomato plants observed in the present study, compared with studies with other begomoviruses in which delivery involved biolistic methods.

Co-infections of viruses in plants can also lead to changes in the kinetics of the systemic invasion of the viruses involved (AlvesJúnior et al. 2009). In the systemic movement of the begomoviruses ToRMV and ToYSV in $N$. benthamiana and tomato plants, positive and negative interactions were observed between the viruses at different stages of the infection. In co-infected plants, when the inoculated leaf was detached at $2 \mathrm{DAI}$ in $N$. benthamiana and at 4 DAI in tomato plants, there was a reduction in the percentage of plants infected with ToYSV compared with plants inoculated with this virus alone. In plants where inoculated leaves were detached at 4 and 6 DAI in $N$. benthamiana and at 8 and 12 DAI in tomato plants, the percentages of ToYSV-infected plants in single or co-infection were similar, while the percentage of plants infected with ToRMV increased in co-infected plants (Alves-Júnior et al. 2009). The authors suggested that the presence of ToRMV interfered with the early events of the ToYSV infection cycle (replication in the initially infected cell or cell-to-cell movement), but ToYSV facilitated the systemic invasion of ToRMV in the later stages in both hosts. In the present study, the systemic invasion of ToSRV was not influenced
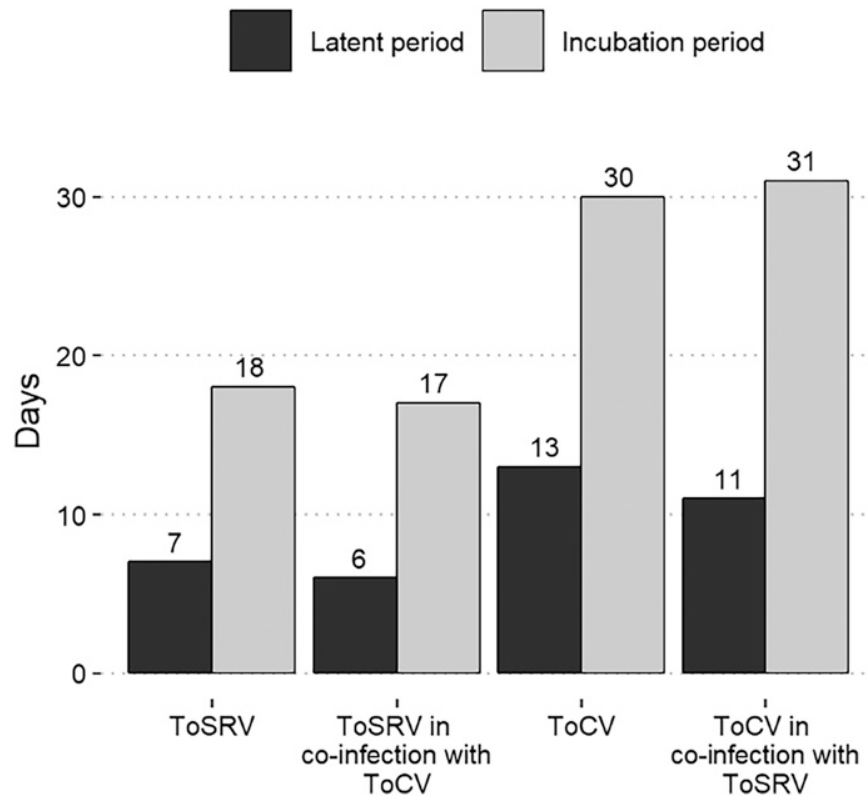

Fig. 2. Mean latent and incubation periods of Tomato severe rugose virus (ToSRV) and Tomato chlorosis virus (ToCV) in single and co-infection in tomato plants. 
by co-infection with ToCV (Fig. 1A and B). The ToCV infection rate for the first experiment was higher in the plants co-infected with ToSRV than in those infected only with this crinivirus, suggesting a positive effect of ToSRV at the beginning of the systemic invasion of ToCV into tomato (Table 1; Fig. 1C). However, this synergistic effect was not observed for the second experiment (Table 1; Fig. 1D).

Latent and incubation periods of ToSRV and ToCV in single and co-infection in tomato plants. The latent period is directly related to the development of epidemics because its length influences the time when the pathogen can be transmitted from a diseased host to another, healthy host (Rimbaud et al. 2015). The latent period is an epidemiological parameter that influences the progress of polycyclic diseases in the field, because the shorter the latent period, the more cycles of the pathogen per host cycle will be obtained, thus increasing the speed at which the epidemic develops (Bergamin Filho et al. 2018).

The results of the present study revealed a significant discrepancy between the onset of host infectivity and the appearance of symptoms induced by ToSRV and ToCV in single and co-infection. Thus, both viruses can be acquired and transmitted from one

\section{Latent period}

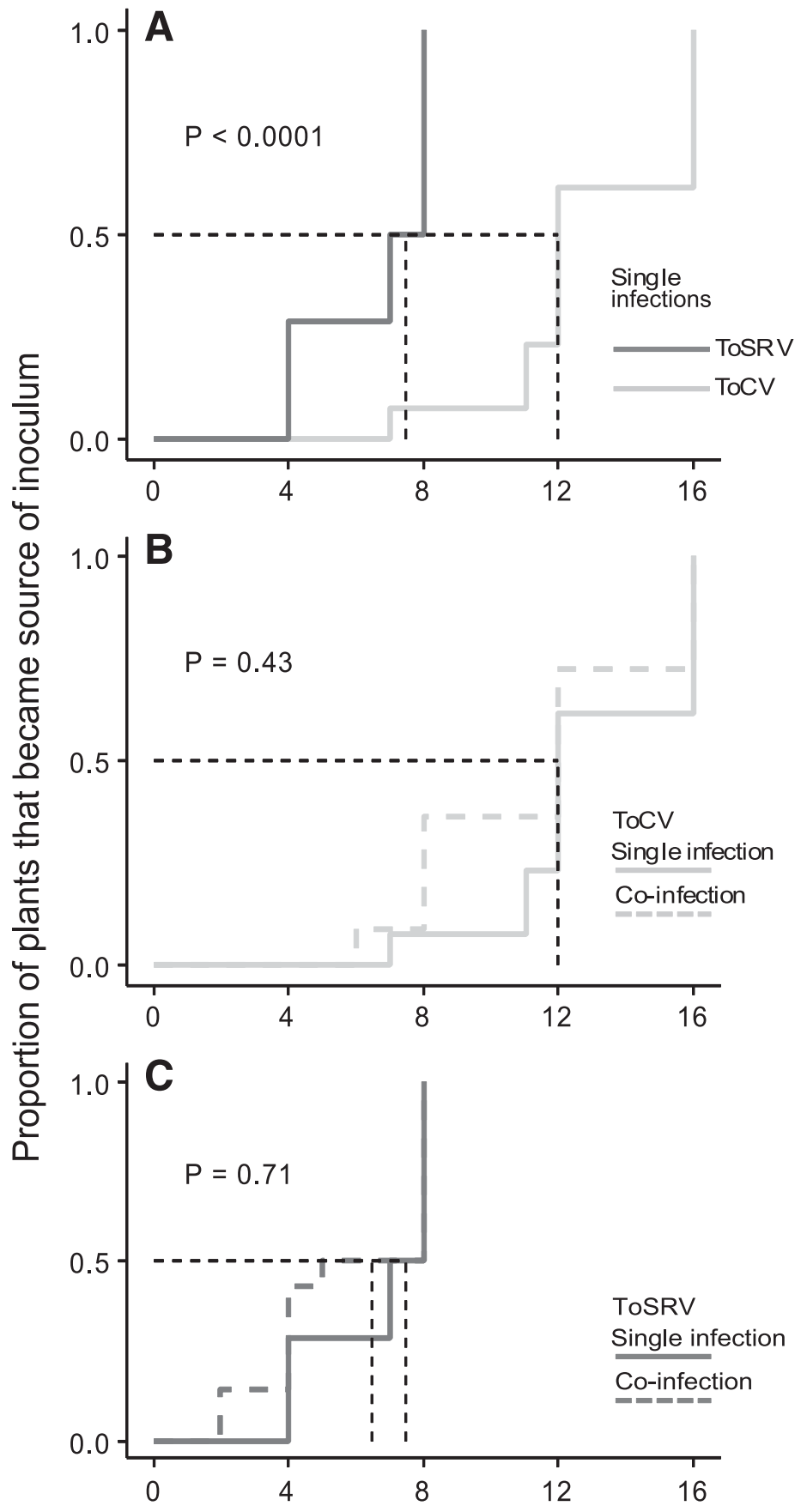

Incubation period

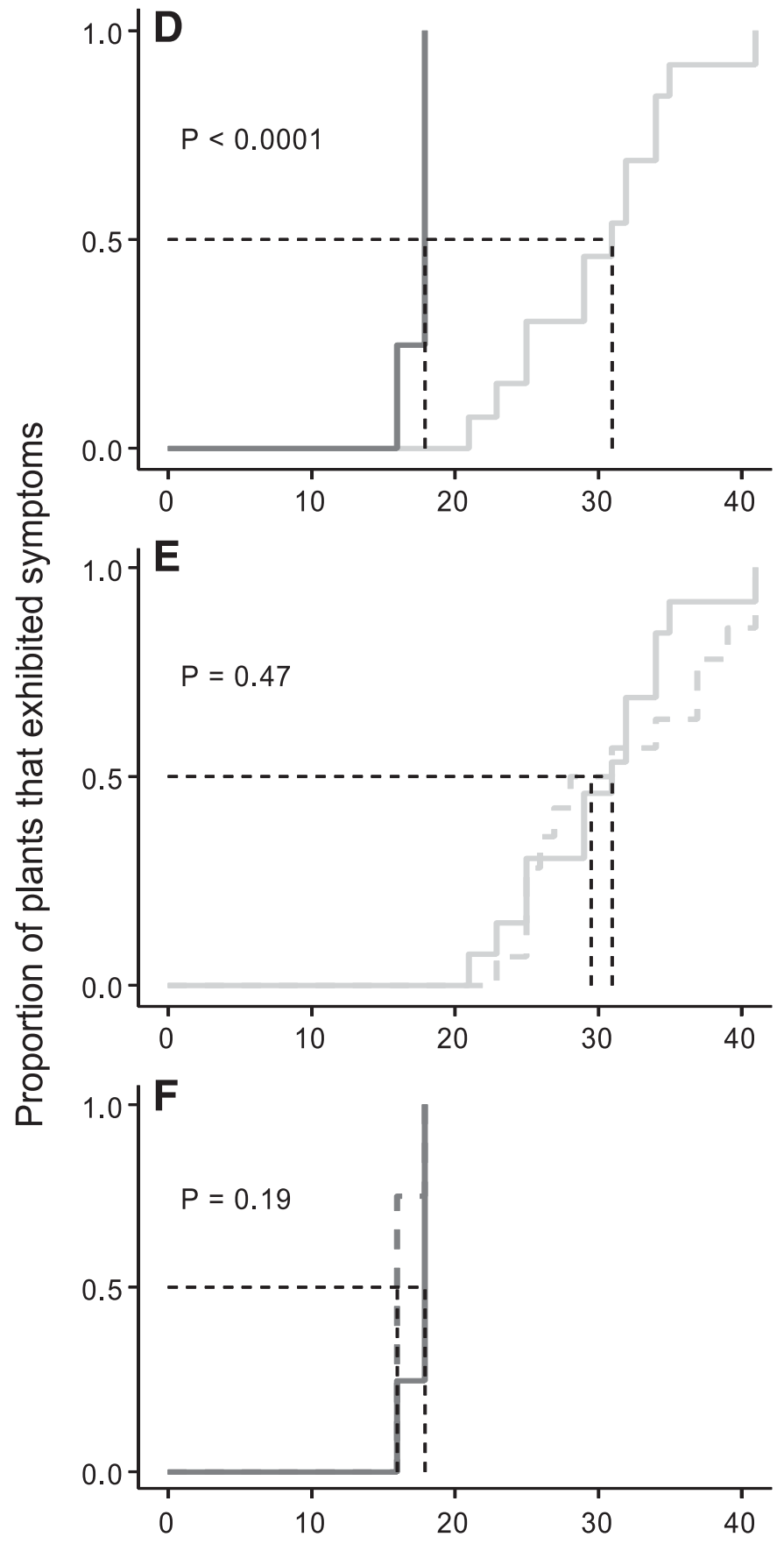

\section{Days after inoculation}

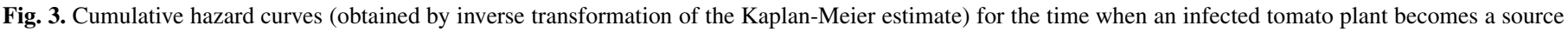

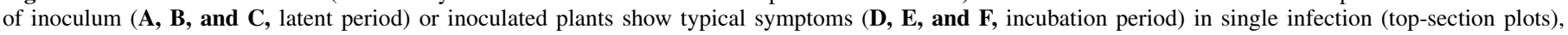

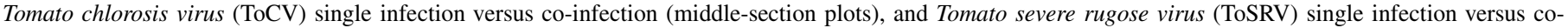
infection (bottom-section plots). 
diseased tomato plant to another healthy one by B. tabaci MEAM1 before any symptoms manifest, because the mean time intervals between the latent and incubation periods for ToCV were 17 days in single infection and 20 days in co-infection with ToSRV. In the case of ToSRV, this time period was 11 days in both types of infection (Table 2; Fig. 2). The long incubation period of ToCV found in this study agrees with those reported by other authors (i.e., that the symptoms of this crinivirus manifested between 18 and 65 DAI in tomato plants) (Barbosa et al. 2008; Orfanidou et al. 2016; Wintermantel and Wisler 2006). For ToSRV, symptoms of interveinal chlorosis, leaf curling, and stunting were observed in infected tomato plants at 3 weeks postinoculation (Macedo et al. 2015).

In contrast to the relatively long-time lag between the latent and incubation periods of ToSRV and ToCV in tomato plants observed here, the latent and incubation periods of the potyvirus Plum pox virus (PPV; genus Potyvirus) in peach trees (Prunus persica) were almost synchronous. Although it is a different pathosystem, the first PPV-induced symptoms in peach leaves appeared 1 day before they became infectious (Rimbaud et al. 2015). The authors also reported that the percentage of peach trees that became infectious increased as a function of time after inoculation.

The importance of the incubation period for plant diseases varies according to specific interactions between the hosts, vectors, and humans. The incubation period is important for diseases for which control measures are based on visible symptoms such as roguing, applied for years with great success to manage papaya mosaic caused by Papaya ringspot virus type $\mathrm{P}$ (genus Potyvirus) in Brazil (Rezende and Kitajima 2018). This control measure interferes with the spread of the pathogen in the field by reducing the period during which the infected plant is available to serve as a source of inoculum. The presence of symptoms may also influence the attraction of the insect vector to the host, which may affect the dissemination of the pathogen (Rimbaud et al. 2015).

Symptoms induced by ToSRV and ToCV in tomato plants may be important visual cues used by B. tabaci MEAM1 to select the host (Fereres et al. 2016). In evaluation of the landing preference of B. tabaci MEAM1 in free-choice tests, where only visual orientation was possible, viruliferous and virus-free insects preferred infected and symptomatic tomato leaves over healthy leaves. In the same study, the preference of virus-free $B$. tabaci MEAM1 for tomato leaves that were healthy or infected with ToSRV or ToCV was evaluated in the presence or absence of light. In the dark, the insects landed indiscriminately on infected and healthy leaves. However, in the presence of light, the insects preferred infected symptomatic leaves rather than healthy leaves. The same study also reported that ToSRV-viruliferous whiteflies preferred volatiles emitted from healthy plants, while volatiles from ToCV-infected plants were avoided by nonviruliferous whiteflies.

The results of the present study show that tomato plants visited by B. tabaci MEAM1, viruliferous for both viruses, are rapidly infected systemically; additionally, the plants can serve as sources of virus inocula for the vector long before they express disease symptoms, especially for ToCV. Thus, from the point of view of managing the diseases caused by these viruses, special care should be taken to produce $100 \%$ virus-free seedlings for transplanting, as previously recommended in other studies (Tzanetakis et al. 2013; Wintermantel et al. 2008). The relatively long and substantially long incubation periods for ToSRV and ToCV, respectively, can cause a delay in visual diagnosis of the disease. Consequently, transplantation of infected seedlings in the field may contribute to the introduction of pathogens into the area early in the planting. These delays also show the epidemiological importance of tomato plants as a source of inocula of both viruses in the field. Therefore, after transplantation of healthy seedlings in the field, other management measures should be prioritized to prevent tomato plants from being infected early. The purpose of delaying the infection time is to reduce the damage caused by ToSRV and ToCV in the tomato crop and to shorten the period during which the infected plants serve as sources of inocula in the field, either as primary sources, for transmission of both viruses between neighboring tomato crops, or as secondary sources, for transmission of viruses between plants of the same crop.

\section{LITERATURE CITED}

Alves-Júnior, M., Alfenas-Zerbini, P., Andrade, E. C., Esposito, D. A., Silva, F. N., Cruz, A. C. F., Ventrella, M. C., Otoni, W. C., and Zerbini, F. M. 2009. Synergism and negative interference during co-infection of tomato and Nicotiana benthamiana with two bipartite begomoviruses. Virology 387:257-266.

Barbosa, J. C., Costa, H., Gioria, R., and Rezende, J. A. M. 2011. Occurrence of Tomato chlorosis virus in tomato crops in five Brazilian states. Trop. Plant Pathol. 36:256-258.

Barbosa, J. C., Teixeira, A. P. M., Moreira, A. G., Camargo, L. E. A., Bergamin Filho, A., Kitajima, E. W., and Rezende, J. A. M. 2008. First report of Tomato chlorosis virus infecting tomato crops in Brazil. Plant Dis. 92:1709.

Barbosa, L. F., Marubayashi, J. M., De Marchi, B. R., Yuki, V. A., Pavan, M. A., Moriones, E., Navas-Castillo, J., and Krause-Sakate, R. 2014. Indigenous American species of the Bemisia tabaci complex are still widespread in the Americas. Pest Manage. Sci. 70:1440-1445.

Bergamin Filho, A., Amorim, L., Willocquet, L., and Savary, S. 2018. Epidemiologia de doenças de plantas. Pages 71-83 in: Manual de Fitopatologia Princípios e Conceitos. L. Amorim, J. A. M. Rezende, and A. Bergamin Filho, eds. Agronômica Ceres, Ouro Fino.

Bergamin Filho, A., Inoue-Nagata, A. K., Bassanezi, R. B., Belasque, J., Jr., Amorim, L., Macedo, M. A., Barbosa, J. C., Willocquet, L., and Savary, S. 2016. The importance of primary inoculum and area-wide disease management to crop health and food security. Food Secur. 8:221-238.

Bergougnoux, V. 2014. The history of tomato: From domestication to biopharming. Biotechnol. Adv. 32:170-189.

Copes, W. E., and Thomson, J. L. 2008. Survival analysis to determine the length of the incubation period of Camellia twig blight caused by Colletotrichum gloeosporioides. Plant Dis. 92:1177-1182.

De Barro, P. J., Scott, K. D., Graham, G. C., Lange, C. L., and Schutze, M. K. 2003. Isolation and characterization of microsatellite loci in Bemisia tabaci. Mol. Ecol. Notes 3:40-43.

Dellaporta, S. L., Wood, J., and Hicks, J. B. 1983. A plant DNA minipreparation: Version II. Plant Mol. Biol. Rep. 1:19-21.

De Marchi, B. R., Marubayashi, J. M., Favara, G. M., Yuki, V. A., Watanabe, L. F. M., Barbosa, L. F., Pavan, M. A., and Krause-Sakate, R. 2017. Comparative transmission of five viruses by Bemisia tabaci NW2 and MEAM1. Trop. Plant Pathol. 42:495-499.

Dovas, C. I., Katis, N. I., and Avgelis, A. D. 2002. Multiplex detection of criniviruses associated with epidemics of a yellowing disease of tomato in Greece. Plant Dis. 86:1345-1349.

Fereres, A., Peñaflor, M. F. G. V., Favaro, C. F., Azevedo, K. E. X., Landi, C. H., Maluta, N. K. P., Bento, J. M. S., and Lopes, J. R. S. 2016. Tomato infection by whitefly-transmitted circulative and non-circulative viruses induce contrasting changes in plant volatiles and vector behaviour. Viruses 8:225.

Fernandes, F. R., Albuquerque, L. C., Britto Giordano, L., Boiteux, L. S., Ávila, A. C., and Inoue-Nagata, A. K. 2008. Diversity and prevalence of Brazilian bipartite begomovirus species associated to tomatoes. Virus Genes 36:251-258.

Gouvêa, M. M., Freitas, D. M. S., Rezende, J. A. M., Watanabe, L. F. M., and Lourenção, A. L. 2017. Bioassay of insecticides on mortality of Bemisia tabaci biotype B and transmission of Tomato severe rugose virus (ToSRV) on tomatoes. Phytoparasitica 45:95-101.

Guimarães, L. R. P., Nozaki, D. N., Moura, M. F., Spadotti, D. M. A., Mituti, T., Krause-Sakate, R., and Pavan, M. A. 2017. Fungicide application can improve production of tomato coinfected with Begomovirus and Crinivirus. Pesqui. Agropecu. Bras. 52:435-442.

Hosmer, D. W., Jr., and Lemeshow, S. 1999. Pages 561-562 in: Applied Survival Analysis: Regression Modelling of Time to Event Data. Wiley, New York.

Hull, R. 2013. Movement of viruses within plants. Pages 531-603 in: Plant Virology, 5th ed. R. Hull, ed. Elsevier/Academic Press, London.

Inoue-Nagata, A. K., Carvalho, C. M., Zerbini, F. M., Rezende, J. A. M., Sakate, R. K., and Nagata, T. 2016a. Vírus transmitidos por moscas-brancas no Brasil: Vetores, principais doenças e manejo. Revisão Anu. Patol. Plantas 24:7-29.

Inoue-Nagata, A. K., Lima, M. F., and Gilbertson, R. L. 2016b. A review of geminivirus diseases in vegetables and other crops in Brazil: Current status and approaches for management. Hortic. Bras. 34:8-18.

Kassambara, A., and Kosinski, M. 2018. Survminer: Drawing Survival Curves using 'ggplot2'. Online publication. R package, version 0.4.3. https://cran. r-project.org/web/packages/survminer/index.html

Lanza, F. E. E., Marti, W., Silva, G. J., Jr., and Behlau, F. 2018. Characteristics of citrus canker lesions associated with premature drop of sweet orange fruit. Phytopathology. In press. doi:10.1094/PHYTO-04-18-0114-R 
Lourenção, A. L., Alves, A. C., Fugi, C. G. Q., and Matos, E. S. 2008. Outbreaks of Trialeurodes vaporariorum (West.) (Hemiptera: Aleyrodidae) under field conditions in the State of São Paulo, Brazil. Neotrop. Entomol. 37:89-91.

Macedo, M. A., Barreto, S. S., Hallwass, M., and Inoue-Nagata, A. K. 2014. High incidence of Tomato chlorosis virus alone and in mixed infection with begomoviruses in two tomato fields in the Federal District and Goiás state, Brazil. Trop. Plant Pathol. 39:449-452.

Macedo, M. A., Inoue-Nagata, A. K., Silva, T. N., Freitas, D. M. S., Rezende, J. A. M., Michereff Filho, M., Nascimento, A. R., Lourenção, A. L., and Bergamin Filho, A. 2019. Temporal and spatial progress of the diseases caused by the crinivirus Tomato chlorosis virus and the begomovirus Tomato severe rugose virus in tomatoes in Brazil. Plant Pathol. 68:72-84.

Macedo, M. A., Michereff Filho, M., Navas-Castillo, J., and Inoue-Nagata, A. K. 2015. Host range and whitefly transmission efficiency of Tomato severe rugose virus and Tomato golden vein virus in tomato plants. Trop. Plant Pathol. 40:405-409.

Madden, L. V., Turechek, W. W., and Nita, M. 2002. Evaluation of generalized linear mixed models for analyzing disease incidence data obtained in designed experiments. Plant Dis. 86:316-325.

Marubayashi, J. M., Yuki, V. A., Rocha, K. C. G., Mituti, T., Pelegrinotti, F. M., Ferreira, F. Z., Moura, M. F., Navas-Castillo, J., Moriones, E., Pavan, M. A., and Krause-Sakate, R. 2013. At least two indigenous species of the Bemisia tabaci complex are present in Brazil. J. Appl. Entomol. 137:113-121.

Mituti, T., Edwards Molina, J. P., and Rezende, J. A. M. 2018. Bioassays on the role of tomato, potato and sweet pepper as sources of Tomato chlorosis virus transmitted by Bemisia tabaci MEAM1. Eur. J. Plant Pathol. 152: 613-619.

Orfanidou, C. G., Pappi, P. G., Efthimiou, K. E., Katis, N. I., and Maliogka, V. I. 2016. Transmission of Tomato chlorosis virus (ToCV) by Bemisia tabaci biotype $\mathrm{Q}$ and evaluation of four weed species as viral sources. Plant Dis. 100:2043-2049.

R Team. 2018. R: A Language and Environment for Statistical Computing. Online publication. R Foundation for Statistical Computing. https://www.rproject.org/
Rezende, J. A. M., and Kitajima, E. W. 2018. Viroses. Pages 369-376 in: Manual de Fitopatologia-Princípios e Conceitos. L. Amorim, J. A. M. Rezende, and A. Bergamin Filho, eds. Agronômica Ceres, Ouro Fino.

Rimbaud, L., Dallot, S., Delaunay, A., Borron, S., Soubeyrand, S., Thébaud, G., and Jacquot, E. 2015. Assessing the mismatch between incubation and latent periods for vector-borne diseases: The case of sharka. Phytopathology 105:1408-1416.

Rocha, C. S., Castillo-Urquiza, G. P., Lima, A. T. M., Silva, F. N., Xavier, C. A. D., Hora-Júnior, B. T., Beserra-Júnior, J. E. A., Malta, A. W. O., Martin, D. P., and Varsani, A. 2013. Brazilian begomovirus populations are highly recombinant, rapidly evolving, and segregated based on geographical location. J. Virol. 87:5784-5799.

Rocha, K. C. G., Marubayashi, J. M., Navas-Castillo, J., Yuki, V. A., Wilcken, C. F., Pavan, M. A., and Krause-Sakate, R. 2011. Only the B biotype of Bemisia tabaci is present on vegetables in São Paulo State, Brazil. Sci. Agric. 68:120-123.

Rojas, M. R., Gilbertson, R. L., Russell, D. R., and Maxwell, D. P. 1993. Use of degenerate primers in the polymerase chain reaction to detect whiteflytransmitted geminiviruses. Plant Dis. 77:340-347.

Scherm, H., and Ojiambo, P. S. 2004. Applications of survival analysis in botanical epidemiology. Phytopathology 94:1022-1026.

Silva, M. S., Wellink, J., Goldbach, R. W., and van Lent, J. W. M. 2002. Phloem loading and unloading of Cowpea mosaic virus in Vigna unguiculata. J. Gen. Virol. 83:1493-1504.

Tzanetakis, I. E., Martin, R. R., and Wintermantel, W. M. 2013. Epidemiology of criniviruses: An emerging problem in world agriculture. Front. Microbiol. 4:119.

Van Der Plank, J. E. 1963. The latent period. Pages 59-74 in: Plant Diseases: Epidemics and Control. J. E. Van Der Plank, ed. Elsevier, New York.

Walsh, P. S., Metzger, D. A., and Higuchi, R. 1991. Chelex-100 as a medium for simple extraction of DNA for PCR based typing from forensic material. Biotechniques 10:506-513.

Wintermantel, W. M., Cortez, A. A., Anchieta, A. G., Gulati-Sakhuja, A., and Hladky, L. L. 2008. Co-infection by two criniviruses alters accumulation of each virus in a host-specific manner and influences efficiency of virus transmission. Phytopathology 98:1340-1345.

Wintermantel, W. M., and Wisler, G. C. 2006. Vector specificity, host range, and genetic diversity of Tomato chlorosis virus. Plant Dis. 90:814-819. 